\title{
CZAS W PERCEPCJI OSÓB POZBAWIONYCH WOLNOŚCI
}

Streszczenie: W artykule poruszono problem postrzegania czasu przez osoby przebywające w zakładach karnych. Każdy skazany niezależnie od tego, czy przebywa w więzieniu po raz pierwszy, czy kolejny, z powodu pozbawienia wolności, a zatem możliwości decydowania o sobie i deprywacji wielu potrzeb, czas teraźniejszy odbiera negatywnie, raczej jako czas fatalistyczny. Osoby obarczone trudnymi doświadczeniami życiowymi mogą koncentrować się na przeszłości, widząc w niej „przyczynę” swojego nieszczęśliwego losu. Z kolei osoby, których życie przed uwięzieniem obfitowało raczej w pozytywne doświadczenia, mogą żyć wspomnieniami, odcinając się emocjonalnie od więziennej rzeczywistości. W pracy z osobami skazanymi niezwykle ważne jest ukierunkowanie ich myślenia na cele i zadania, które będą realizować w przyszłości, po odbyciu kary. Badania percepcji czasu przeprowadzono z 80 kobietami (50 z nich pierwszy raz odbywało karę i 30 było recydywistkami) oraz z 60 mężczyznami (30 z nich po raz pierwszy odbywało karę i 30 było recydywistami). W badaniach posłużono się Kwestionariuszem Postrzegania Czasu Philipa Zimbardo. Analizę statystyczną uzyskanych wyników przeprowadzono przy pomocy pakietu statystycznego SPSS.

Słowa kluczowe: percepcja czasu, kobiety pierwszy raz odbywające karę, kobiety recydywistki, mężczyźni pierwszy raz odbywający karę, mężczyźni recydywiści.

\section{Wprowadzenie}

Pojęcie czasu, przez wszystkich powszechnie używane, jest bardzo trudne do zdefiniowania. Już św. Augustyn pytany o to, czym jest czas, twierdził, że jest to pojęcie mgliste. Trudność jego zdefiniowania wynika z problemu miary oraz ludzkiej skłonności do poszukiwania analogii między miarami czasowymi i przestrzennymi.

\footnotetext{
* Dr hab. Aleksandra Korwin-Szymanowska, prof. uczelni, Akademia Ekonomiczno-Humanistycznaw Warszawie; e-mail: korwisz@wp.pl.
} 
Psychologowie zajmowali się czasem w relacyjnym ujęciu. Zdaniem Arthura Rebera, „tylko dzięki niemu można choć w części zadawalająco nadać ramy pojęciowe psychologicznemu doświadczaniu czasu, długości jego trwania i rozciągłości oraz zmiennym konotacjom takich słów, jak przeszłość, teraźniejszość przyszłość, teraz, potem" (Reber 2002, s. 12).

Philip Zimbardo, który wraz z współpracownikami przeprowadził szereg wywiadów i badań $\mathrm{z}$ ludźmi w różnym wieku, perspektywę czasu definiuje jako proces, za pomocą którego jednostka porządkuje swoje osobiste doświadczenia, dzieląc je na strefy czasowe: przeszłość, teraźniejszosśc i przyszłość. Perspektywa czasowa odzwierciedla postawy, przekonania i wartości odnoszące się do czasu. Myśląc o przeszłości, teraźniejszości czy przyszłości ważne jest, czy myśli te są pozytywne, czy negatywne, radosne, czy smutne, pełne nadziei, czy lęku. Zdaniem Zimbardo, poznanie perspektywy postrzegania czasu w odniesieniu do konkretnej osoby, pomaga w ustaleniu odpowiedzi na tego typu pytania, i pozwala odzwierciedlić jednocześnie myśli, odczucia i zachowania (Zimbardo, Boyd 2014, s. 51). Perspektywa postrzegania czasu to zdaniem Zimbardo i Boyda, „osobiste nastawienie - często nieuświadomione, które każdy z nas przejawia wobec czasu. Jest to również proces, $\mathrm{w}$ ramach którego bezustanny bieg życia zostaje podzielony na kategorie czasowe, pomagając nadać naszemu życiu porządek, spójność i znaczenie" (Zimbardo, Boyd 2014 s. 50).

Aby pomóc ludziom w poprawie ich psychofizycznego funkcjonowania, zwłaszcza tkwiącym w negatywnej przeszłości czasowej lub fatalistycznej teraźniejszości, Zimbardo opracował Kwestionariusz Percepcji Czasu, który pozwala na ustalenie przyjętej przez badanego perspektywy czasowej i w zależności od uzyskanych wyników - podjęcie terapii.

W kwestionariuszu postrzegania czasu Philip Zimbardo (ZTPI) wyróżnił pięć perspektyw postrzegania czasu, a mianowicie: przeszłość negatywną, przeszłość pozytywną, teraźniejszą hedonistyczną, teraźniejszą fatalistyczną i przyszłą.

Zdaniem twórców cytowanego kwestionariusza, optymalny profil perspektywy czasu charakteryzuje:

- $\quad$ wysoka przeszłościowa - pozytywna perspektywa czasu;

- umiarkowanie wysoka przyszłościowa perspektywa czasu;

- umiarkowanie wysoka teraźniejszo-hedonistyczna perspektywa czasu;

- niska przeszłościowa - negatywna perspektywa czasu;

- niska teraźniejszo-fatalistyczna perspektywa czasu (Zimbardo, Boyd 2014, s. 248).

Tworzenie celów życiowych i podejmowanie aktywności, które pomogą w realizacji tych celów, utrudnia przyjęcie perspektywy teraźniejszo-fatalistycznej i negatywna perspektywa przeszłościowa. Osoby przyjmujące zwłaszcza perspektywę teraźniejszo-fatalistyczną cechuje depresyjność, niestabilność emocjonalna, małe poczucie własnej wartości, skłonność do przeżywania lęku, mała sumienność. 
Dorosły człowiek współczesny, żyjący zwłaszcza w krajach wysoko uprzemysłowionych, narzeka często na brak czasu. Życie jego wypełnione jest pracą lub troską o rodzinę. Formułuje plany na przyszłość, ale często żyje „tu i teraz”.

Dla człowieka pozbawionego wolności, często siedzącego bezczynnie w celi, pozbawionego możliwości swobodnego działania i kontaktu z osobami bliskimi, czas nabiera szczególnego znaczenia. Niektórzy przyjmują perspektywę przeszłościową i żyją wspomnieniami odnoszonych „sukcesów”, lub też rozpamiętują doznane krzywdy i popełnione błędy. Osoby, zwłaszcza te skazane na długoletnie kary pozbawienia wolności, często odcinają się od przeszłości, nie myślą o przyszłości i koncentrują się na teraźniejszości. Przyjęcie jako techniki radzenia sobie z dolegliwościami w sytuacji uwięzienia wycofania się polega, zdaniem Ervina Goffmana, na odcięciu się skazanego od otoczenia i koncentracji wyłącznie na sobie i tym, co go dotyczy bezpośrednio. Ten typ przystosowania oznacza również zobojętnienie na sprawy innych ludzi oraz ucieczkę w świat marzeń i fantazji (por. Ciosek 2003). Większość osób pozbawionych wolności snuje jednak plany na przyszłość, choć wielu z nim brak wiary w to, że uda im się je kiedykolwiek zrealizować.

Szczególnie trudno wyznaczać cele i plany na przyszłość osobom, które większość swego życia spędziły w instytucjach zamkniętych, we wczesnej młodości w zakładach wychowawczych, a w dorosłości w więzieniach.

Wśród kobiet skazanych na długoletnie kary znaczny odsetek stanowią kobiety skazane za zabójstwa (por. Szczepanik 2008). Zdaniem J. Cegielskiej, pewna część kobiet odbywających kary za zabójstwo to osoby, które z ofiar przemocy w rodzinie stały się przestępcami. Pomimo tego, że często działały w obronie własnej lub w obronie dzieci, lub działały w afekcie, nadal tkwią w poczuciu krzywdy i własnej bezradności, a wyrok uważają za zbyt surowy. Szczególnie dotkliwie odczuwają rozłąkę z dziećmi, których nie potrafiły obronić przed przemocą (Cegielska 2005, cyt. za: Machel 2006, s. 216).

Jak wynika z badań przeprowadzonych przez M. Teleszyńską, dzieci kobiet odbywających karę pozbawienia wolności po ich aresztowaniu często trafiają do rodzin zastępczych, zostają pod opieką ojca lub dziadków, a jeżeli nie mają nikogo bliskiego, kto mógłby się nimi zaopiekować, kierowane są do domów dziecka. Brak kontaktu z dziećmi lub kontakt bardzo ograniczony jest przez nie bardzo silnie odczuwany (Teleszyńska 2018).

Ponieważ kobiety wśród osób przebywających w aresztach śledczych i zakładach karnych stanowią od trzech do czterech proc. wszystkich osadzonych, bardzo niewiele badań poświęconych jest tej grupie osób. Z obserwacji uwięzionych kobiet i z przeprowadzonych badań wynika, że kobiety dużo gorzej niż mężczyźni znoszą izolację więzienną, niekiedy tracą poczucie bezpieczeństwa, są rozdrażnione, cechuje je niska samoocena, brak wiary w siebie. Personel więzienny stara się łagodzić te negatywne stany poprzez zwiększenie kontaktów z domem rodzinnym, zwłaszcza z dziećmi, zachęcanie do podejmowania pracy, nauki zawodu, a także 
do udziału w zajęciach kulturalno-sportowych i terapeutycznych, o ile skazana osoba jest uzależniona od alkoholu lub narkotyków.

W grudniu 2019 roku w zakładach karnych i aresztach śledczych przebywało łącznie 74130 osób, w tym 8520 tymczasowo aresztowanych, 65291 skazanych (w tym 2697 kobiet) i 917 ukaranych. Wśród osób skazanych było 37171 recydywistów penitencjarnych, czyli osób, które w zakładzie karnym przebywały co najmniej po raz drugi (Roczna informacja statystyczna za rok 2019, MS, CZSS).

Walka z recydywą przez obostrzania kar, zdaniem wielu przedstawicieli doktryny, jak i kryminologów, nie rozwiązuje problemu, dłuższa bowiem izolacja tych skazanych od społeczeństwa nie ma istotnego wpływu na powrót do świata przestępczego, ponieważ takie zdarzenia są wynikiem bardzo wielu czynników, a także sytuacji codziennych, z jakimi styka się w społeczeństwie osoba opuszczająca więzienie (Szczygieł 2019, s. 491). Jak słusznie zauważył M. Foucault, „,kazani to w znacznej mierze dawni więźniowie”, bowiem "po wyjściu z więzienia jest więcej szans niż przedtem by tam wrócić" (Foucault 1975, s. 319).

Jak wynika z badań przeprowadzonych przez B. Kwiatkowskiego, osadzeni recydywiści istotnie częściej niż osoby przebywające w zakładzie karnym po raz pierwszy wykazują proaktywność adaptacyjną, podczas gdy osoby odbywające karę pozbawienia więzienia po raz pierwszy, mimo znacznych ograniczeń, jakie stwarza sytuacja izolacji, podejmują działania proaktywne, które mogą pomóc im w realizacji planów życiowych po opuszczeniu więzienia (Kwiatkowski 2019). Można więc przyjąć, że recydywiści przyjmują perspektywę czasu teraźniejszego hedonistycznego istotnie częściej niż osoby osadzone po raz pierwszy, które myślą również o przyszłości i wyznaczają sobie cele do zrealizowaniu po wyjściu $\mathrm{z}$ więzienia.

\section{Cel badań}

Celem badań prezentowanych w niniejszym opracowaniu było ustalenie:

- jakie perspektywy czasu przyjmują osoby pozbawione wolności;

- czy pod względem przyjmowanej perspektywy czasu osadzone kobiety różnią się od osadzonych mężczyzn;

- czy pod względem przyjmowanej perspektywy czasu osoby po raz pierwszy odbywające karę pozbawienia wolności różnią się od recydywistów;

- czy istnieje zależność między wiekiem osadzonych oraz okresem pozostałym do końca kary a przyjmowaną przez nich perspektywą czasu.

\section{Metoda badań}

W badaniach wykorzystano Kwestionariusz Postrzegania Czasu Zimbardo (The Zimbardo Time Perspective Inventory ZTPI) w polskiej adaptacji A. Przepiórki. Kwestionariusz składa się z 56 stwierdzeń. Zadaniem osoby badanej jest 
ustosunkowanie się do każdego z nich i zaznaczenie na pięciostopniowej skali, czy zgadza się z danym stwierdzeniem całkowicie, czy też zupełnie się nie zgadza.

Stosunek do czasu przeszłego negatywnego mierzony jest przez 10 stwierdzeń, do czasu teraźniejszego hedonistycznego - przez 14 stwierdzeń, do czasu przyszłego - przez 13 stwierdzeń, zaś do czasu przeszłego pozytywnego - przez dziewięć stwierdzeń i czasu teraźniejszego fatalistycznego - również przez dziewięć stwierdzeń.

\section{Charakterystyka osób badanych}

Badania przeprowadzono w czterech zakładach karnych, obejmując nimi łącznie 140 osób. W grupie badanych było 80 kobiet (50 kobiet pierwszy raz odbywających karę pozbawienia wolności i 30 recydywistek) i 60 mężczyzn (30 pierwszy raz osadzonych i 30 recydywistów).

Wiek badanych przedstawiono w tabeli pierwszej.

Tabela 1. Wiek badanych (w proc.)

\begin{tabular}{|l|c|c|c|c|}
\hline \multirow{2}{*}{ Wiek } & \multicolumn{2}{|c|}{ Kobiety $\mathrm{N}=80$} & \multicolumn{2}{c|}{ Mężczyźni N =60 } \\
\cline { 2 - 5 } & $\begin{array}{c}\text { Karane po raz } \\
\text { pierwszy } \\
\mathrm{N}=50\end{array}$ & $\begin{array}{c}\text { Recydywistki } \\
\mathrm{N}=30\end{array}$ & $\begin{array}{c}\text { Karani po raz } \\
\text { [pierwszy } \\
\mathrm{N}=30\end{array}$ & $\begin{array}{c}\text { Recydywiści } \\
\mathrm{N}=30\end{array}$ \\
\hline Do 25 lat & 6 & 20 & 6,6 & 13,4 \\
\hline $26-30$ & 16 & 16,7 & 30 & 16,6 \\
\hline $31-40$ & 20 & 33,3 & 30 & 30 \\
\hline $41-50$ & 30 & 20 & 20 & 20 \\
\hline 51 i więcej lat & 14 & 10 & 6,7 & - \\
\hline Brak danych & 14 & - & 6,7 & 20 \\
\hline
\end{tabular}

Zarówno wśród badanych kobiet, jak i mężczyzn najliczniej reprezentowane były osoby w wieku 31-50 lat. Można też stwierdzić, że zarówno wśród kobiet, jak i mężczyzn w wieku do 25 lat znacznie mniejszy odsetek stanowiły osoby, które odbywały karę pozbawienia wolności po raz pierwszy niż wśród recydywistów. Z kolei odsetek kobiet pierwszy raz odbywających karę w wieku powyżej 40 lat wynosił 44 proc., a w grupie mężczyzn po raz pierwszy karanych $-26,7$ proc.

Okres pozostałej do odbycia kary pozbawienia wolności przedstawiono w tabeli drugiej. 
Tabela 2. Okres pozostałej do odbycia kary (w proc.)

\begin{tabular}{|c|c|c|c|c|}
\hline \multirow[b]{2}{*}{ Okres pozostałej kary } & \multicolumn{2}{|c|}{$\begin{array}{l}\text { Kobiety } \\
\mathrm{N}=8 \mathrm{O}\end{array}$} & \multicolumn{2}{|c|}{$\begin{array}{c}\text { Mężczyźni } \\
\mathrm{N}=60\end{array}$} \\
\hline & $\begin{array}{c}\text { Karane po raz } \\
\text { pierwszy } \\
\mathrm{N}=50\end{array}$ & $\begin{array}{l}\text { Recydywistki } \\
\qquad \mathrm{N}=30\end{array}$ & $\begin{array}{c}\text { Karani po raz } \\
\text { pierwszy } \\
\mathrm{N}=30\end{array}$ & $\begin{array}{c}\text { Recydywiści } \\
\mathrm{N}=30\end{array}$ \\
\hline Do 1 roku & 14 & 36,7 & 16,7 & 50 \\
\hline Powyżej 1 roku do 2 lat & 8 & 33,3 & 23,3 & 16,8 \\
\hline Powyżej 2 lat do 3 lat & 18 & 13,4 & 23,3 & 20 \\
\hline Powyżej 3 lat do 5 lat & 20 & - & 13,4 & 6,6 \\
\hline Powyżej 5 lat & 24 & 6,6 & 6,6 & 6,6 \\
\hline Brak danych & 16 & 10 & 6,7 & - \\
\hline
\end{tabular}

Jak wynika z przedstawionych powyżej danych, najdłuższy okres pozostałej do odbycia kary dotyczy kobiet po raz pierwszy przebywających w więzieniu powyżej 24 proc., a w analogicznej grupie mężczyzn - tylko 6,6 proc. Nie można wykluczyć, że część z nich uzyska warunkowe przedterminowe zwolnienie z odbywania kary i wcześniej opuści więzienie, niemniej perspektywa długoletniego pobytu w izolacji musi wpływać na ich funkcjonowanie psychofizyczne, a także myślenie o przyszłości.

Najkrótszy czas, jaki dzielił badanych od zwolnienia, dotyczył recydywistów, którzy często popełniają drobne przestępstwa, w związku z czym skazywani są też na krótkie kary. Długoterminowe kary orzekane są natomiast wobec sprawców zabójstw i innych poważnych przestępstw.

\section{Prezentacja wyników badań}

Ponieważ badane grupy kobiet i mężczyzn różniły się między sobą zarówno pod względem wieku, jak i okresu pozostałej do odbycia kary pozbawienia wolności postanowiono sprawdzić, czy istnieje związek między wiekiem i pozostałym okresem kary pozbawienia wolności a preferowaną perspektywą czasową. Wyniki korelacji r-Pearsona przedstawiono w tabeli trzeciej.

Tabela 3. Wiek, koniec kary a wyniki ZTPI

\begin{tabular}{|l|c|c|c|c|c|}
\hline & $\begin{array}{c}\text { Przeszły } \\
\text { negatywny }\end{array}$ & $\begin{array}{c}\text { Teraźniejszy } \\
\text { hedonistyczny }\end{array}$ & Przyszły & $\begin{array}{c}\text { Przeszły } \\
\text { pozytywny }\end{array}$ & $\begin{array}{c}\text { Teraźniejszy } \\
\text { Fatalistyczny }\end{array}$ \\
\hline Wiek & $-0,08$ & $-0,24^{*}$ & 0,03 & $-0,06$ & $-0,005$ \\
\hline Koniec kary & 0,12 & $-0,04$ & 0,07 & $-0,05$ & 0,00 \\
\hline
\end{tabular}

${ }^{* *}$-p $<0.01$

Jak wynika z przedstawionych danych, stwierdzono istotny statystycznie ujemny związek między wynikami w skali perspektywy teraźniejszo-hedonistycznej 
a wiekiem badanych. Nie jest to związek zbyt silny, niemniej można powiedzieć, że im wyższy był wiek badanych, uzyskiwali oni niższe wyniki w tej podskali. Zależność ta wydaje się zrozumiała, gdyż ludzie młodzi w znacznie większym stopniu niż starsi dążą do czerpania przyjemności z życia, wybierają działania pobudzające i ekscytujące, unikają natomiast działań wymagających wysiłku lub tych, które uważają za nudne.

Zimbardo w oparciu o przeprowadzone badania zarówno w Stanach Zjednoczonych, jak i wielu krajach europejskich opracował „idealną” perspektywę czasu. Wyniki porównania tej „idealnej” perspektywy czasu z perspektywą przyjmowaną przez badanych więźniów przedstawiono w tabeli czwartej.

Tabela 4. Idealna perspektywa czasu a średnie wyniki więźniów

\begin{tabular}{|l|c|c|c|c|}
\hline \multicolumn{1}{|c|}{ Perspektywa } & $\begin{array}{c}\text { Idealna perspektywa } \\
\text { czasu } \\
(\mathrm{M})\end{array}$ & $\begin{array}{c}\text { Perspektywa czasu } \\
\text { więźniów } \\
(\mathrm{M})\end{array}$ & $\mathrm{T}$ & $\mathrm{P}$ \\
\hline Przeszły negatywny & 2,10 & 3,28 & 18,84 & 0 \\
\hline Teraźniejszy hedonistyczny & 4,33 & 3,19 & $-22,51$ & 0 \\
\hline Przyszły & 3,69 & 3,20 & $-9,43$ & 0 \\
\hline Przeszły pozytywny & 3,67 & 3,23 & $-7,53$ & 0 \\
\hline Teraźniejszy fatalistyczny & 1,67 & 2,98 & 23,13 & 0 \\
\hline
\end{tabular}

Porównując przedstawione powyżej wyniki, można stwierdzić, że badana grupa więźniów uzyskała istotnie statystycznie wyższe wyniki w skalach: czas teraźniejszy fatalistyczny oraz czas przeszły negatywny, natomiast istotnie niższe wyniki w skalach: czas teraźniejszy hedonistyczny, przyszły i przeszły pozytywny. Największa różnica dotyczy postrzegania czasu teraźniejszego fatalistycznego, co wydaje się zrozumiałe, biorąc pod uwagę fakt, że więźniowie są pozbawieni wolności i przebywają w więzieniu, jak również to, że mają za sobą przeszłość, która postrzegana jest przez znaczną część z nich jako zbiór negatywnych doświadczeń.

Wyniki powyższe należy jednak traktować jedynie jako orientacyjne, gdyż idealna perspektywa czasu nie była weryfikowana wśród polskiej populacji, niemniej wydaje się, że osoby pozbawione wolności z uwagi na sytuację, w jakiej się znajdują, pod względem percepcji swojej przeszłości, a także możliwości planowania przyszłości, różnią się od osób, które przebywają na wolności.

Ponieważ znaczna część kobiet odbywających karę pozbawienia wolności posiada dzieci, postanowiono sprawdzić, czy częściej niż mężczyźni kobiety myślą o przyszłości. Perspektywy czasu przyjmowane przez kobiety i mężczyzn przedstawiono $\mathrm{w}$ tabeli piątej. Aby stwierdzić, czy istnieją różnice między myśleniem kobiet i mężczyzn, zastosowano test t-Studenta. 
Tabela 5. Perspektywy czasu badanych kobiet i mężczyzn

\begin{tabular}{|c|c|c|c|c|c|c|}
\hline & \multicolumn{2}{|c|}{ Kobiety $M=80$} & \multicolumn{2}{|c|}{ Mężczyźni M =6o } & \multirow{2}{*}{$\mathrm{T}$} & \multirow{2}{*}{$\mathrm{P}$} \\
\hline & $\mathrm{M}$ & SD & M & SD & & \\
\hline Przeszły negatywny & 3,46 & 0,79 & 3,05 & 0,61 & 3,61 & $\mathrm{o}$ \\
\hline $\begin{array}{l}\text { Teraźniejszy } \\
\text { hedonistyczny }\end{array}$ & 3,28 & 0,63 & 3,07 & 0,54 & 2,09 & 0,04 \\
\hline Przyszły & 3,41 & 0,61 & 2,92 & 0,51 & 5,02 & $\mathrm{o}$ \\
\hline Przeszły pozytywny & 3,40 & 0,74 & 3,00 & 0,54 & 3,59 & $\mathrm{O}$ \\
\hline $\begin{array}{l}\text { teraźniejszy } \\
\text { fatalistyczny }\end{array}$ & 2,94 & 0,74 & 3,03 & 0,55 & $-0,80$ & $-0,42$ \\
\hline
\end{tabular}

Jak wynika z przedstawionych powyżej danych, brak istotnych różnic odnotowano jedynie w stosunku badanych do czasu teraźniejszego fatalistycznego. Izolacja więzienna, deprywacja wielu istotnych potrzeb sprawiają, że przez osoby pozbawione wolności, niezależnie od płci, czas teraźniejszy przeżywany jest jako sytuacja trudna.

Największe różnice między badanymi kobietami i mężczyznami dotyczą przyszłej perspektywy czasu, co może świadczyć o tym, że kobiety myśląc o przyszłości, istotnie częściej niż mężczyźni planują działania i stawiają sobie cele, które będą chciały po odzyskaniu wolności zrealizować. Sprawdzono również, czy pod tym względem kobiety pierwszy raz karane różnią się od recydywistek. Obliczenia wykonane przy pomocy testu t-Studenta przedstawiono w tabeli szóstej.

Jak wynika z przedstawionych powyżej danych, kobiety pierwszy raz odbywające karę pozbawienia wolności różnią się istotnie od recydywistek postawą wobec czasu. Największe różnice dotyczą przyszłej perspektywy czasu i wydaje się to zrozumiałe, biorąc pod uwagę fakt, że recydywistkom w przeszłości nie udało się zrealizować planów i rozpocząć życia zgodnego z obowiązującymi normami społecznymi, a zatem obecnie raczej koncentrują się na czasie teraźniejszym niż przyszłym.

Tabela 6. Perspektywa czasu wśród kobiet karanych po raz pierwszy i recydywistek

\begin{tabular}{|l|c|c|c|c|c|c|}
\hline \multirow{2}{*}{\begin{tabular}{c}
\multirow{2}{*}{$\begin{array}{c}\text { Perspektywa } \\
\text { czasu }\end{array}$} \\
\cline { 2 - 5 }
\end{tabular}} & \multicolumn{2}{|c|}{$\begin{array}{c}\text { Pierwszy raz karane } \\
\mathrm{N}=50\end{array}$} & \multicolumn{2}{c|}{$\begin{array}{c}\text { Recydywistki } \\
\mathrm{N}=30\end{array}$} & \multirow{2}{*}{$\mathrm{T}$} & $\mathrm{P}$ \\
\cline { 2 - 5 } $\begin{array}{l}\text { Przeszły } \\
\text { negatywny }\end{array}$ & - & 0,79 & 3,15 & 0,69 & 2,819 & 0,006 \\
\hline $\begin{array}{l}\text { Teraźniejszy } \\
\text { hedonistyczny }\end{array}$ & 3,39 & 0,65 & 3,10 & 0,56 & 2,056 & 0,044 \\
\hline Przyszły & 3,61 & 0,58 & 3,07 & 0,51 & 4,143 & 0 \\
\hline $\begin{array}{l}\text { Przeszły } \\
\text { pozytywny }\end{array}$ & 3,59 & 0,59 & 3,09 & 0,87 & 3,100 & 0,003 \\
\hline
\end{tabular}




\begin{tabular}{|l|c|c|c|c|c|c|}
\hline \multirow{2}{*}{$\begin{array}{c}\text { Perspektywa } \\
\text { czasu }\end{array}$} & \multicolumn{2}{|c|}{$\begin{array}{c}\text { Pierwszy raz karane } \\
\mathrm{N}=50\end{array}$} & \multicolumn{2}{|c|}{$\begin{array}{c}\text { Recydywistki } \\
\mathrm{N}=30\end{array}$} & \multirow{2}{*}{$\mathrm{T}$} & $\mathrm{P}$ \\
\cline { 2 - 5 } & $\mathrm{M}$ & $\mathrm{SD}$ & $\mathrm{M}$ & $\mathrm{SD}$ & & \\
\hline $\begin{array}{l}\text { Teraźniejszy } \\
\text { fatalistyczny }\end{array}$ & 2,89 & 0,78 & 3,14 & 0,64 & $-2,003$ & 0,049 \\
\hline
\end{tabular}

Sprawdzono również, czy istnieją różnice w postrzeganiu czasu między mężczyznami pierwszy raz odbywającymi karę a recydywistami. Wyniki porównań przedstawiono w tabeli siódmej.

Tabela 7. Perspektywa czasu mężczyzn pierwszy raz odbywających karę pozbawienia wolności i recydywistów

\begin{tabular}{|l|c|c|c|c|c|c|}
\hline \multirow{2}{*}{ Perspektywa czasu } & \multicolumn{2}{|c|}{\begin{tabular}{c} 
Pierwszy raz karani \\
\cline { 2 - 5 }
\end{tabular}} & \multicolumn{2}{|c|}{$\begin{array}{c}\text { Recydywiści } \\
\text { N }=30\end{array}$} & \multirow{2}{*}{$\mathrm{T}$} & \multirow{2}{*}{$\mathrm{P}$} \\
\cline { 2 - 5 } & 3,12 & 0,66 & 2,98 & 0,56 & 0,907 & 0,368 \\
\hline Przeszły negatywny & 3,05 & 0,48 & 3,10 & 0,60 & $-0,356$ & 0,723 \\
\hline $\begin{array}{l}\text { Teraźniejszy } \\
\text { hedonistyczny }\end{array}$ & 2,97 & 0,56 & 2,86 & 0,47 & 0,849 & 0,339 \\
\hline Przyszły & 2,96 & 0,45 & 3,03 & 0,63 & $-0,471$ & 0,639 \\
\hline Przeszły pozytywny & 2,88 & 0,47 & 3,17 & 0,59 & $-2,113$ & 0,039 \\
\hline $\begin{array}{l}\text { Teraźniejszy } \\
\text { fatalistyczny }\end{array}$ & & & & &
\end{tabular}

Jedyna różnica istotna statystycznie, dotycząca postrzegania czasu między mężczyznami pierwszy raz odbywającymi karę pozbawienia wolności i recydywistami, dotyczy czasu teraźniejszego fatalistycznego. Okazało się, że recydywiści, pomimo tego, że znają realia życia więziennego, czas teraźniejszy postrzegają znacznie gorzej niż osoby przebywające w zakładzie karnym po raz pierwszy.

Przedstawione w niniejszym opracowaniu wyniki badań wskazują, że sposób postrzegania czasu przez osoby pozbawione wolności może znacznie utrudniać im funkcjonowanie psychospołeczne, zarówno podczas odbywania kary, jak również po opuszczeniu więzienia.

Znaczna część badanych, zarówno kobiet, jak i mężczyzn ma za sobą negatywne przeżycia, do których wracają pamięcią i które mogą im uniemożliwiać tworzenie planów na przyszłość.

Praca resocjalizacyjna z osobami pozbawionymi wolności powinna zmierzać do pomocy im w zrozumieniu przyczyn swych negatywnych doświadczeń życiowych i do podjęcia decyzji o zmianie postaw wobec siebie, innych ludzi i życia, czyli nastawieniu się na przyszłość przez formułowanie celów i zadań, które już w trakcie odbywania kary mogą zacząć realizować.

Ponieważ wśród osadzonych kobiet i mężczyzn znaczny odsetek stanowią osoby uzależnione od alkoholu, konieczne zatem wydaje się objęcie ich terapią, a także 
zachęcanie do podjęcia pracy i szkolenia w zawodach, jakie po zwolnieniu z więzienia będą mogły wykonywać.

Jak wynika z badań K. Mirosław, kobiety odbywające karę dążą do zatrudnienia w zakładzie karnym, głównie po to, aby zdobyć pieniądze na zaspokojenie swoich potrzeb żywnościowych, higienicznych, kupno papierosów (65 proc.), i uzyskanie oszczędności (36 proc.). Głównym motywem starań o pracę jest chęć „zabicia czasu" (50 proc.), zdobycia pieniędzy (65 proc.) podniesienie kwalifikacji zawodowych (38 proc.) i lubienie pracy (Mirosław 2009). Niezwykle ważne jest również, zwłaszcza w pracy resocjalizacyjnej z kobietami, udzielanie im pomocy w utrzymywaniu więzi z rodzinami.

\section{Bibliografia}

Ciosek M. (2003). Psychologia sądowa i penitencjarna. Warszawa: Wydawnictwo Lexis Nexis.

Foucault M. (1975). Nadzorować i karać. Narodziny więzienia. Warszawa: Wydawnictwo Spacja.

Kwiatkowski B. (2019). Wybrane cechy osobowości a zachowania proaktywne osób pozbawionych wolności (rozprawa doktorska). Warszawa: AEH.

Machel H. (2006). Sens i bezsens resocjalizacji penitencjarnej. Studium penitencjarno-pedagogiczne. Kraków: Wydawnictwo Impuls.

Mirosław K. (2009). Aktywność zawodowa osadzonych kobiet droga do wolności W: Zagadnienia readaptacji społecznej skazanych. F. Kozaczuk (red.). Rzeszów: Wydawnictwo Uniwersytetu Rzeszowskiego.

Roczna informacja statystyczna za 2018 rok. M.S. CZSS

Szczepanik R. (2008). Struktura i dynamika przestępczości kobiet. W: Resocjalizacja. Ciagłość i zmiana. Konopczyński M., Nowak B.M. (red.). Warszawa: Wydawnictwo WSPR.

Szczygieł G. (2019). Recydywa penitencjarna - kilka refleksji: Po co nam kryminologia.. W: Księga Jubileuszowa Profesor Ireny Rzeplińskiej. Klaus W., Woźniakowska-Fajst D., Wiktorska P., Buczkowski K. (red.). Warszawa: Wydawnictwo INP PAN.

Teleszewska M. (2018). Wykonywanie kary pozbawienia wolności wobec kobiet (praca doktorska). Białystok: Wydział Prawa, Uniwersytet w Białymstoku.

Zimbardo P., Boyd J. (2014). Paradoks czasu. Warszawa: Wydawnictwo PWN. 


\title{
TIME PERCEIVED BY INCARCERATED PERSONS
}

\begin{abstract}
The article deals with the problem of perception of time by incarcerated people. Every convict, regardless of whether he or she is imprisoned for the first time or is a repeater, perceives the present time negatively, as a fatalistic time because the imprisonment deprives them ofthe possibility to decide for themselves. People burdened with difficult life experiences may focus on the past, seeing it as the „cause” of their unhappy fate. On the other hand, people whose life before imprisonment was rather full of positive experiences may live in memories cutting themselves off emotionally from the prison reality. When working with convicted persons, it is extremely important to direct their thinking towards goals and tasks that they will carry out in the future, after serving their sentence. The research on time perception was conducted with 80 women ( 50 first time offenders and 30 recidivists) and 60 men (30 first time offenders and 30 recidivists). The research was conducted using the Philip Zimbardo Time Perception Questionnaire. Statistical analysis of the obtained results was carried out using the SPSS statistical package.
\end{abstract}

Keywords: perception of time, first time offenders, female offenders, first time offenders, male offenders. 